\title{
Innovation Activity of the Polish Manufacturing Enterprises
}

\author{
Arkadiusz Kijek • Mariusz Lisowski • \\ Waclawa Starzyńska
}

Published online: 30 November 2012

(C) The Author(s) 2012. This article is published with open access at Springerlink.com

\begin{abstract}
This paper presents the results of analysis of innovative activities in the Polish manufacturing enterprises. Using data for the years 2006-2009, the effectiveness of innovative activities is estimated under two groups of models. The results indicate the significantly positively impact of soft expenditures on innovation activity and ineffectiveness of material outlays. Additionally, a significant, positive effect is demonstrated of the support from the European Union upon the efficiency of innovative activities in the Polish companies.
\end{abstract}

Keywords Innovation activity $\cdot$ Manufacturing sector $\cdot$ Logit model

JEL $\mathrm{C} 10 \cdot \mathrm{L} 60 \cdot \mathrm{O} 10 \cdot \mathrm{O} 52$

\section{Introduction}

In recent years during the world's economic crisis, a lot of significance has been attributed to developing innovative activities in enterprises that allow them to not only survive in such a difficult period, but also to develop and expand. Through offering new or improved products or services, they can increase their sales in both domestic and foreign markets.

Public programs directing financial support from domestic and EU means for Polish entrepreneurs also stimulate the development of innovative activities in companies. In these programs, special emphasis is put on implementing new technologies

\footnotetext{
A. Kijek $(\bowtie) \cdot$ M. Lisowski $\cdot$ W. Starzyńska

Department of Statistics and Econometrics, Maria Curie-Skłodowska University, Lublin, Poland e-mail: akijek@poczta.umcs.lublin.pl

M. Lisowski

e-mail: Mariusz.Lisowski@umcs.lublin.pl

W. Starzyńska

e-mail: wacstar@uni.lodz.pl
} 
and introducing innovations in all the areas of enterprise activity. The criteria of assessing application motions are established in such a way that the recruitment results significantly depend upon the degree of project innovativeness. Consequently, subsidies are first granted to all firms that accomplish innovative projects.

Considering the importance of the issue, the authors attempt to assess the influence of outlay on innovative activity, as well as of support from public resources upon the effects of these activities in the Polish industrial enterprises. The aim of the paper is, firstly, to verify the expectation of greater effectiveness of outlay on the so-called "soft" areas (R\&D activity, knowledge purchase, and software) than on the material components of property. Another purpose was to compare the effectiveness of supporting innovative activities from public resources coming from domestic and foreign sources. Numerous empirical studies aimed at identifying the sources of progress are based on the function of production expanded by the new factor, which characterizes the scientific research potential of a given economy, firstly measured by accumulated expenditures on R\&D or innovative activity. These kinds of studies have been conducted since the mid-twentieth century, and they included, among others, the works of such scholars as Griliches (1957, 1979), Schmookler (1966), and Mansfield (1968). The results of these studies, which were conducted mainly on the level of enterprises and economy branches, proved the existence of a positive relationship between the size of outlay on innovative activity and economic development. Studies about the effectiveness of innovative undertakings were also conducted by Kijek and Kijek (2010a, b), who assessed the relationship between the outlay and the effects of innovative activity in the EU countries. Monreal-Perez et al. (2011) examined the mutual relationships between innovative activities and being prone to export in enterprises.

The paper is divided into two parts: the methodological and the empirical. In the following sections, an introduction to the issues of innovativeness in economic activities is made. The section following that is devoted to the characterization of innovative actions in Polish enterprises, whereas in the subsequent section, the effects of this activity are described. The final section is devoted to the presentation of research methods and results of the conducted empirical studies.

\section{Innovativeness}

Both the integration of Poland with the European Union and the processes of globalization resulted in opening particular markets to the competitive fight of subjects and enterprises functioning in the economy at home and abroad. The growing freedom of capital flow and the global market of raw materials and components significantly decreases the barriers of entering particular markets. Also, the activity of international corporations enhances the intensity of competition between subjects through promotion and unification of human lifestyles, as well as the consumption models in particular countries.

In such economic conditions, enterprises must incessantly develop and adjust their offers to changes in the market, to customers' expectations, and to the actions of their competitors in order to remain competitive and maintain their market positions. Thus, the competitiveness of enterprises depends upon the effects of many processes and 
mechanisms, both endogenous (inherent in the enterprise), and exogenous (external, resulting from broadly understood economic, administrative, or cultural surroundings). According to the definition by the Organization for Economic Co-operation and Development (OECD), the competitiveness of enterprises means the ability to secure high return rate on the applied production factors and maintain high employment levels. In literature, competitiveness is also defined as:

- Permanent ability to maintain development, production, and sales;

- Ability to achieve benefits exceeding alternative applications of capital; and

- Ability to achieve surplus of receipts over costs, profit and rate of return, as well as to maintain the position of a leader, the leading subject in the market.

Both in the sphere of research (scientific) and in productive (technical), commercial (sales), managing (organizing), and financial (investment) activities, a significant factor determining the competitiveness of enterprises is the innovation of their approach, the basic aim of which is to work out and implement new, significantly improved products and processes (these products and processes are new at least from the point of view of the implementing subjects). Thus, the results of innovative processes could be, for instance, new products, services, technologies, a specific position in the market, or organizational changes in the enterprise.

\section{Taxonomy of Innovation}

Performing the ultimate taxonomy of innovation is very difficult. The areas where it occurs interpenetrate, the particular types of innovations are interrelated, and the same types of innovation can frequently belong to several classification groups. In the literature, the dichotomous division of innovations (the division into product and process innovations) is most frequently encountered, especially in the technological area. However, it does not exhaust all kinds of innovations also occurring in other non-technological areas, such as implementing advanced management techniques; introducing new organizational structures, new action strategies, and innovations in the marketing communication channels; changes of aesthetic nature; or other creative modifications of an enterprise's products. Figure 1 presents an attempt at innovation taxonomy according to various criteria.
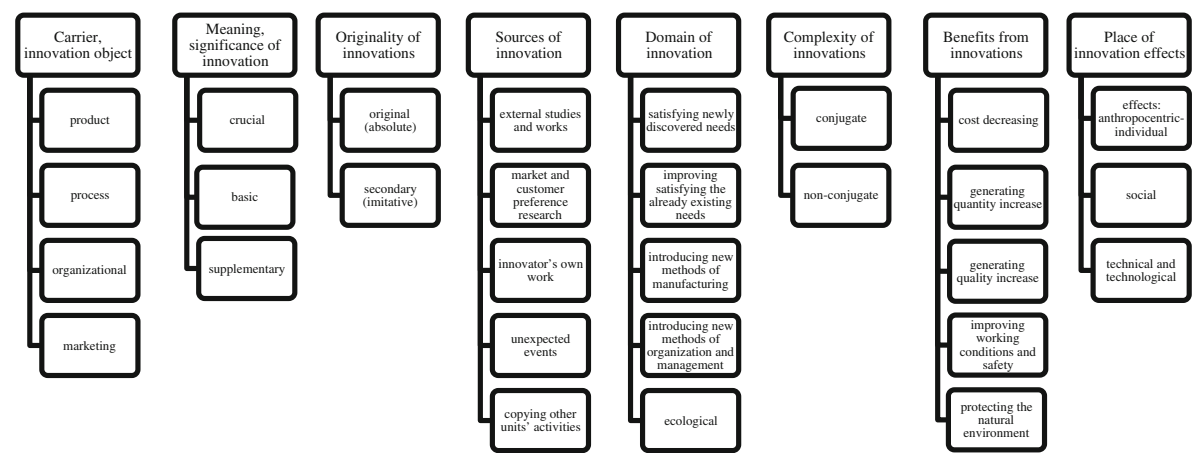

Fig. 1 Taxonomy of innovation 
The division of innovations, which is key to this paper, differentiates among product, process, organizational, and marketing innovations. The remaining classifications define, among others, the innovation impulse's origin, significance, innovative novelty degree, complexity of the innovation process, innovation effects, etc.

In Poland, the main source of information on innovative activities in the national economy is the Central Statistical Office (CSO), which, undertaking an innovation, assumes the implementation of a new or significantly improved product (commodity, service) or process, a new method of organization or a new marketing method in the economic practice, workplace organization, or in the relationships with the surroundings. A new or significantly improved product is implemented when it is launched (introduced onto the market). New organizational or marketing methods and processes are implemented when their actual use in the activity of an enterprise begins. The definitions of particular main kinds of innovations, adopted by $\mathrm{CSO}$, are the following:

Product innovation introduces a commodity or service that is new or significantly improved in its features or applications into the market. Product innovations in services involve introducing significant improvements in the manner of rendering the services, adding new functions or features to the already existing services, or introducing completely new services.

Process innovation implements new or significantly improved methods of production, distribution, and supporting activities concerning commodities and services. Process innovations include new or significantly improved methods of creating and rendering services. They also comprise new or significantly improved techniques, appliances, and software in auxiliary activities, such as supplies, accountancy, information technology service, and maintenance works.

Organizational innovation implements a new method of organization in the principles of work assumed by an enterprise, in workplace organization, or in the relationships with the surroundings that have not yet been applied in a given enterprise. Organizational innovations must result from strategic decisions taken by the management. They do not include fusions and takeovers, even if they were made for the first time.

Marketing innovation is the implementation of a new marketing idea or strategy, significantly differing from marketing methods hitherto applied in a given enterprise. Marketing innovations include significant changes in product structures, packages, product distribution, product promotion, and price forming. They do not include seasonal changes, regular, or other routine changes in marketing methods. Marketing changes are aimed at satisfying the customers' needs better, opening new sales markets, or new positioning of an enterprise's product on the market to increase sales.

\section{Innovative Activity of the Polish Enterprises in the Years 2008-2010}

The share of industrial and service sector enterprises that introduced innovations in the years 2008-2010 in Poland equaled $17.1 \%$ and $12.8 \%$ respectively. Higher 
percentages, both in industrial enterprises and the service sector were reported in the public sector ${ }^{1}$ (respectively $27.3 \%$ and $22.2 \%$ ) than in the private sector ${ }^{2}$ (respectively $16.6 \%$ and $12.5 \%$ ).

The results of examining the innovative activity in Poland demonstrate that in industrial enterprises and in those from the services sector the higher share was that of enterprises, which in the years 2008-2010 introduced process innovations (new or significantly improved processes), than those with product innovations (new or significantly improved products). An innovative product and process were both introduced by $7.9 \%$ of industrial enterprises and $5.1 \%$ of subjects from the services sector, which is presented in detail by Fig. 2.

Considering the property sectors, higher percentages of subjects that introduced product and process innovations, both among the industrial enterprises and those from the services sector were reported in the public sector. Most of the process innovations introduced by industrial enterprises in the years 2008-2010 concerned new or significantly improved methods of manufacturing (production) of commodities and services $(10.0 \%)$, and in the services sector-new or significantly improved methods (systems) supporting processes in an enterprise (7.6\%), which is presented in detail in Table 1, were introduced.

The results of examining innovativeness show that among both the industrial enterprises and those from the services sector, which introduced product innovations in the years 2008-2010, the highest percentage was that of subjects who worked out the implemented product innovations themselves (respectively $73.5 \%$ and $56.1 \%$ ). A similar situation was in the case of process innovations $-54.8 \%$ of industrial enterprises and $44.0 \%$ of those from the services sector worked out the innovations introduced in the examined period on their own.

In the years 2008-2010, organizational innovations were implemented by $13.0 \%$ of industrial enterprises and $15.2 \%$ of the enterprises from services sector. Among the industrial enterprises and those from the services sector, a higher share of units that decided to implement new methods of organization was reported in the public sector (respectively $15.8 \%$ of industrial enterprises and $18.7 \%$ of those from the services sector) than in the private sector (respectively $12.9 \%$ and $15.1 \%$ ).

In the years 2008-2010, a higher share of enterprises that introduced marketing innovations was reported among subjects from the services sector $(15.5 \%$ of enterprises) than in industry (13.5\% of examined units). The share of industrial enterprises from the private sector, which introduced new marketing methods in the years under discussion was higher by 2.8 percentage points than the value of this index in the public sector, where it was $10.8 \%$. In the services sector, a higher value of this share was reported for subjects from the public sector $(16.5 \%)$, compared to $15.4 \%$ in the private sector.

\footnotetext{
${ }^{1}$ The public sector comprises the property of the State (of the State Treasury and of the state legal persons, the property of local government and mixed property with the predominance of capital (property) of the public sector subjects.

${ }^{2}$ The private sector comprises domestic and foreign private property, as well as mixed property with the predominance of capital (property) of the private sector subjects.
} 
Fig. 2 Innovative enterprises in the years $2008-2010$ in \% of enterprises total, according to kinds of innovation

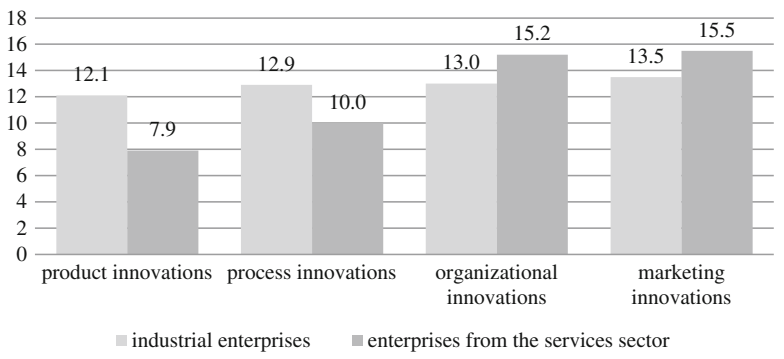

\section{Economic Aspects of Innovative Activity}

Innovative activity concerns particular areas of an enterprise's work and should be consistent with the main purpose of its functioning. Thus, the innovative activity should first of all be effective. According to the standards for assessing the effects of innovative activity of an enterprise, the information that is used concerns the share of revenues in a given year from selling new or significantly improved products (net revenues from selling products, i.e. commodities, services, goods, and materials) introduced onto the market within last 3 years in the total revenues value. This index constitutes important information about the influence of product innovations upon the general structure of revenues and on the level of innovativeness in the enterprise.

The share of net revenues from selling new or significantly improved products introduced onto the market in the years 2008-2010 in total revenues from sales in the year 2010 was $11.3 \%$ for industrial enterprises in Poland and $4.1 \%$ for the subjects

Table 1 Innovative enterprises in the years 2008-2010 in \% of total number of enterprises in accordance with kinds of innovation and property sectors

\begin{tabular}{|c|c|c|c|c|c|c|c|}
\hline \multirow[t]{3}{*}{ Specification } & & \multicolumn{6}{|c|}{$\begin{array}{l}\text { Enterprises that introduced innovations in \% of total number of enterprises in } \\
\text { the years } 2008-2010\end{array}$} \\
\hline & & \multirow[t]{2}{*}{ Total } & \multirow{2}{*}{$\begin{array}{l}\text { Significantly } \\
\text { improved } \\
\text { products }\end{array}$} & \multirow{2}{*}{$\begin{array}{l}\text { Significantly } \\
\text { improved } \\
\text { processes }\end{array}$} & \multicolumn{3}{|l|}{ Including } \\
\hline & & & & & $\begin{array}{l}\text { Methods of } \\
\text { manufacturing } \\
\text { products }\end{array}$ & $\begin{array}{l}\text { Methods of } \\
\text { logistics and/ } \\
\text { or supply and } \\
\text { distribution } \\
\text { methods }\end{array}$ & $\begin{array}{l}\text { Methods } \\
\text { supporting } \\
\text { processes }\end{array}$ \\
\hline \multirow{3}{*}{$\begin{array}{l}\text { Industrial } \\
\text { enterprises }\end{array}$} & Total & 17.1 & 12.1 & 12.9 & 10.0 & 3.3 & 6.4 \\
\hline & $\begin{array}{l}\text { Public } \\
\text { sector }\end{array}$ & 27.3 & 12.5 & 22.6 & 13.7 & 5.2 & 14.5 \\
\hline & $\begin{array}{l}\text { Private } \\
\text { sector }\end{array}$ & 16.6 & 12.1 & 12.4 & 9.8 & 3.2 & 5.9 \\
\hline \multirow{3}{*}{$\begin{array}{l}\text { Enterprises } \\
\text { from services } \\
\text { sector }\end{array}$} & Total & 12.8 & 7.9 & 10.0 & 3.7 & 4.0 & 7.6 \\
\hline & $\begin{array}{l}\text { Public } \\
\text { sector }\end{array}$ & 22.2 & 13.9 & 17.4 & 7.2 & 5.7 & 13.7 \\
\hline & $\begin{array}{l}\text { Private } \\
\text { sector }\end{array}$ & 12.5 & 7.7 & 9.8 & 3.6 & 4.0 & 7.4 \\
\hline
\end{tabular}


from the services sector. A higher share of revenues from innovative products in total revenues was reported for both the industry and the services sector in the public sector, respectively $13.9 \%$ and $6.8 \%$.

In the year 2010, the expenditures incurred on innovative activity ${ }^{3}$ in the group of industrial enterprises equaled 23,757.8 million Polish zloty (PLN), whereas in the services sector, these expenditures were more than two times lower and equaled 10,790.3 million PLN. Most of the expenditures for innovative activity were incurred by the enterprises from the private sector. In industrial enterprises, these expenditures constituted $73.7 \%$ of all expenditures on innovative activity, whereas in service enterprises it was $88.7 \%$.

In the year 2010, enterprises, both industrial and service-sector, designated most of their means for purchasing machines and technical appliances for transport, tools, devices, movables, and equipment. These expenditures constituted $52.6 \%$ of all the expenditures on innovative activity in industrial enterprises and $41.7 \%$ in enterprises from the services sector. The lowest outlay on innovative activity in industrial and service-sector enterprises was incurred for staff training directly related to introducing product or process innovations (less than $1.0 \%$ ).

The main source of financing the outlay on innovative activity in the year 2010 was the enterprises' own funds, which constituted $75.2 \%$ of all the expenditures in industrial enterprises and $85.7 \%$ in the service-sector enterprises. Among the innovatively active enterprises, both industrial and those from the service sector, most obtained public support from the European Union (respectively $17.1 \%$ and $12.6 \%$ ). Every tenth innovatively active industrial enterprise and $5.3 \%$ of the subjects from the services sector received support from domestic institutions.

\section{Methodology and Study Results}

The analysis of the effectiveness of innovative actions undertaken by processing industry entrepreneurs requires comparing the outlays on innovation and their effects. In order to achieve this, the relationships between the quantity of expenditures for innovative activities in enterprises, production effectiveness, and market expansion were examined. The effect of public financial support upon innovative activity was also measured.

The source of data for the performed study was the information contained in the publication by the Central Statistical Office entitled "Innovation Activities of Enterprises during 2006-2009" (2010). The study contains the results of examining the innovative activity of industrial enterprises in the years 2006-2008 and of examining innovative activity in the services sector in the years 2006-2008, based on the questionnaire and methodology of Community Innovation Survey 2008 (CIS 2008), as well as on the results of the abridged study in the years 2007-2009. The 23 divisions grouped in $\mathrm{D}$ section-manufacturing industry - were the objects of the analysis.

\footnotetext{
${ }^{3}$ All expenditures for product and process innovations are examined: current and investment, incurred in the reporting year for successful works (e.g. when an innovation was implemented), unfinished (continued) and discontinued or abandoned before completion, regardless of the sources of their financing.
} 
The study was divided into two parts. In the first part, the effect of the quantity of outlay on innovative activities in manufacturing enterprises was determined on the changes in manufacturing effectiveness, product innovativeness, and the market expansion level. In the second part, the degree of influence of public support from domestic institutions and European Union on the effectiveness of innovative activities was estimated.

For this purpose, models describing relationships among the effects of innovative activities, the level of expenditures, and financial support were used. Due to the fact that the percentage of enterprises was the dependent variables, the linear regression model for levels of variables was not applicable (Ramanathan 1989). Thus, a transformation of limited variable $P$ was performed according to the formula $\mathrm{Y}=\operatorname{logit}(\mathrm{P})=\ln [\mathrm{P} /(1-\mathrm{P})]$, and logit model parameters were estimated:

$$
Y=\ln \left[\frac{P}{(1-P)}\right]=\alpha_{0}+\alpha_{1} X_{1}+\alpha_{2} X_{2}+\cdots+\alpha_{k} X_{k}+\varepsilon
$$

The parameters of the model were estimated using the ordinary least squares method. To remove the insignificant variables affecting the explained variable, backward elimination was used. When the explanatory variables were restricted variables, their logit transformation was also performed according to the following formula: $\mathrm{Z}=\operatorname{logit}(\mathrm{X})=\ln [\mathrm{X} /(1-\mathrm{X})]$.

In this study, the following were dependent variables:

$P_{1} \quad$ The percentage of enterprises that introduced innovations

$P_{2}$ The percentage of revenues from selling products that are new to the market in enterprises

$P_{3} \quad$ The percentage of revenues from selling products that are new only to the enterprise

$P_{4}$ The percentage of enterprises that introduced innovations worked out on their own

$P_{5} \quad$ The percentage of enterprises that introduced innovations worked out in cooperation with other enterprises and/or domestic scientific institutions

$P_{6} \quad$ The percentage of enterprises that introduced innovations worked out in cooperation with other enterprises and/or foreign scientific institutions

$P_{7} \quad$ The percentage of enterprises that introduced organizational innovations

$P_{8} \quad$ The percentage of enterprises that introduced marketing innovations.

As explanatory variables the following variables were assumed:

$X_{1} \quad$ Outlay on R\&D activity on the enterprise in current prices

$X_{2}$ Outlay on knowledge purchase from external sources on the enterprise in current prices

$X_{3} \quad$ Outlay on software purchase on the enterprise in current prices

$X_{4} \quad$ Outlay on machines and technical appliances on the enterprise in current prices

$X_{5} \quad$ Outlay on staff training connected with innovative activity on the enterprise in current prices

$X_{6}$ Outlay on marketing concerning the new and significantly improved products on the enterprises in millions of PLN 
$X_{7} \quad$ Percentage of innovatively active enterprises that obtained public financial support for innovative activity from domestic institutions, and

$X_{8} \quad$ Percentage of innovatively active enterprises that obtained public financial support for innovative activity from the European Union.

In the first group of models illustrating the effectiveness of influence exerted by the particular kinds of outlay on the innovative activity, the explanatory variables were $X_{1}, X_{2}, X_{3}, X_{4}, X_{5}$, and $X_{6}$, and the dependent variables were: $P_{1}, P_{2}$, $P_{3}, P_{7}$ and $P_{8}$. In the second group of models describing the effect of domestic and EU support upon the effectiveness of innovative activity, $X_{7}$ and $X_{8}$, were assumed as explanatory variables, whereas the dependent variables were $P_{1}, P_{3}, P_{4}, P_{5}, P_{6}, P_{7}$, and $P_{8}$. The estimate parameter from the first group are presented in Table 2, and those from the second group are presented in Table 3.

The results from the first group indicate that the first three variables, expenditures for R\&D activity, expenditures for purchasing knowledge from external sources, and expenditures for purchasing software, significantly positively affect innovative actions in all the examined areas. The material outlays for purchasing machines and appliances, staff training, and marketing outlay were ineffective or had a negative influence (shown by negative parameter estimates) on the effectiveness of introducing innovations in enterprises and the level of new products sales. However, the marketing and training expenditures significantly positively affect the implementation of marketing innovations in enterprises.

In the second group, the obtained parameter estimates unanimously indicate a positive influence of the support from European Union resources on the effectiveness of undertaken innovative activities. The support from domestic resources did not have a single-direction effect upon the results of innovative activities; it negatively affected

Table 2 Parameter estimates and test statistics for the models of innovative activity effects to the level of outlay

\begin{tabular}{llllll}
\hline & $\operatorname{logit}\left(P_{1}\right)$ & $\operatorname{logit}\left(P_{2}\right)$ & $\operatorname{logit}\left(P_{3}\right)$ & $\operatorname{logit}\left(P_{7}\right)$ & $\operatorname{logit}\left(P_{8}\right)$ \\
\hline Const & $-1.430^{* * *}$ & $-3.001^{* * *}$ & $-3.139^{* * *}$ & $-2.135^{* * *}$ & $-1.965^{* * *}$ \\
$X_{1}$ & $0.336^{*}$ & $\mathrm{x}$ & $\mathrm{x}$ & $0.55^{* * *}$ & $\mathrm{x}$ \\
$X_{2}$ & $\mathrm{x}$ & $10.891^{* *}$ & $6.733^{*}$ & $\mathrm{x}$ & $\mathrm{x}$ \\
$X_{3}$ & $1.925^{* * *}$ & $18.678^{* * *}$ & $2.199^{* *}$ & $\mathrm{x}$ & $0.849^{* *}$ \\
$X_{4}$ & $\mathrm{x}$ & $-0.132^{* *}$ & $\mathrm{x}$ & $\mathrm{x}$ & $\mathrm{x}$ \\
$X_{5}$ & $\mathrm{x}$ & $-33.946^{* *}$ & $-20.449^{* *}$ & $10.947^{* * *}$ & $4.899^{*}$ \\
$X_{6}$ & $\mathrm{x}$ & $-4.727^{*}$ & $\mathrm{x}$ & $\mathrm{x}$ & $1.511^{* *}$ \\
$R^{2}$ & 0.525 & 0.382 & 0.341 & 0.527 & 0.590 \\
$\mathrm{TR}^{2}(p$-value $)$ & $1.45(0.92)$ & $16.56(0.68)$ & $10.70(0.30)$ & $7.89(0.16)$ & $4.10(0.90)$ \\
$\chi^{2}(p$-value $)$ & $1.23(0.54)$ & $1.08(0.58)$ & $2.92(0.23)$ & $3.57(0.17)$ & $2.27(0.31)$ \\
\hline
\end{tabular}

$\mathrm{x}$ - eliminated variable, $\mathrm{TR}^{2}$ - White's test statistic for heteroskedasticity of the random disturbance, $\chi^{2}-$ chi-square statistics in Doornik-Hansen test for normality of random disturbance

*Statistical significance at 0.1 level, $* *$ Statistical significance at 0.05 level, $* * *$ Statistical significance at 0.01 level 
Table 3 Parameter estimates and test statistics for the models of innovative activity to the size of domestic and EU support

\begin{tabular}{llllllll}
\hline & $\operatorname{logit}\left(P_{1}\right)$ & $\operatorname{logit}\left(P_{3}\right)$ & $\operatorname{logit}\left(P_{4}\right)$ & $\operatorname{logit}\left(P_{5}\right)$ & $\operatorname{logit}\left(P_{6}\right)$ & $\operatorname{logit}\left(P_{7}\right)$ & $\operatorname{logit}\left(P_{8}\right)$ \\
\hline Const & $0.348^{*}$ & $-2.26^{* * *}$ & -0.27 & -0.072 & $-2.659^{* * *}$ & $-1.148^{* * *}$ & $-1.887^{* * *}$ \\
$\operatorname{logit}\left(X_{7}\right)$ & $0.303^{* *}$ & $\mathrm{x}$ & $-1.024^{* * *}$ & $\mathrm{x}$ & $0.543 * *$ & $-0.824^{* *}$ & $-0.126^{*}$ \\
$\operatorname{logit}\left(X_{8}\right)$ & $0.321^{* *}$ & $0.376^{* *}$ & $\mathrm{X}$ & $1.117^{* * *}$ & $\mathrm{x}$ & $0.786^{* *}$ & $\mathrm{x}$ \\
$R^{2}$ & 0.212 & 0.191 & 0.790 & 0.51 & 0.245 & 0.260 & 0.135 \\
$\mathrm{TR}^{2}(p$-value $)$ & $2.54(0.77)$ & $0.55(0.76)$ & $0.68(0.71)$ & $2.36(0.31)$ & $0.47(0.79)$ & $3.72(0.59)$ & $0.53(0.77)$ \\
$\chi^{2}(p$-value $)$ & $0.13(0.94)$ & $4.24(0.12)$ & $8.65(0.01)$ & $26.97(0.00)$ & $7.03(0.03)$ & $2.40(0.30)$ & $2.77(0.25)$ \\
\hline
\end{tabular}

$\mathrm{x}$ - eliminated variable, $\mathrm{TR}^{2}$ - White's test statistic for heteroskedasticity of the random disturbance, $\chi^{2}-$ chi-square statistics in Doornik-Hansen test for normality of random disturbance

*Statistical significance at 0.1 level, $* *$ Statistical significance at 0.05 level, $* * *$ Statistical significance at 0.01 level

the independence of innovative activities in enterprises and the innovativeness in the spheres of organization and marketing. This means that domestic support, contrary to foreign support, did not reveal clear-cut positive effects. Thus, solutions should be sought that improve usage of financial resources from domestic institutions designed for developing innovations in enterprises.

\section{Conclusions}

This article was devoted to the problems of innovativeness, especially the influence of outlay on innovative activity and support from public resources upon the effects of such activities in Polish industrial enterprises. This study confirms the effectiveness of outlay on innovative activity. The enterprises achieve the most measurable effects through expenditures on R\&D activity, knowledge purchase from external sources, and software purchase. Additionally, a significant, positive effect was demonstrated of assistance resources from the European Union on the effectiveness of innovative activities in Polish enterprises.

This study allowed for the initial assessment of the innovative activities conducted by Polish enterprises. The presence of Poland in the EU structures makes it possible to expand the range of studies on an international level and thus it will constitute the basis for comparing the effectiveness of innovative actions of individual national economies within the EU.

Open Access This article is distributed under the terms of the Creative Commons Attribution License which permits any use, distribution, and reproduction in any medium, provided the original author(s) and the source are credited. 


\section{References}

Griliches, Z. (1957). Specification bias in estimates of production functions. Journal of Farm Economics, $39(1), 8-20$.

Griliches, Z. (1979). Issues in Assessing the Contribution of R\&D to Productivity Growth. Bell Journal of Economics, 10(1), 92-116.

Innovation Activities of Enterprises during 2006-2009 (2010). Central Statistical Office, Warszawa.

Kijek, A., \& Kijek, T. (2010a). The analysis of innovation input-output relationships in EU member states. Comparative Economic Research, 13(1), 93-106.

Kijek, A., \& Kijek, T. (2010b). The Comparative Analysis of Innovation Performance In EU Countries, Acta Universitatis Lodziensis, Folia Oeconomica 241, Macroeconomic Aspects of European Integration, 193-204.

Mansfield, E. (1968). The economics of technological change. New York: W.W. Norton and Co.

Monreal-Perez, J., Aragon-Sanchez, A., \& Sanchez-Marin, G. (2011). A longitudinal study of the relationship between export activity and innovation in the Spanish Firm: the moderating role of productivity. International Business Review. doi:10.1016/j.ibusrev.2011.09.010.

Ramanathan, R. (1989). Introductory econometrics with applications. San Diego: University of California. Schmookler, J. (1966). Invention and economic growth. Cambridge: Harvard University Press. 